\title{
VERONIKA BOCSI
}

\section{The share of academic time in student lifestyle ${ }^{\mathrm{i}}$}

(Hungarian Educational Research Journal, vol. 3. issue 3. (2013). DOI: 10.14413/herj2013.03.08)

\begin{abstract}
Literature on student lifestyle defines academic time as the timeframe that covers studyrelated activities. Notably this definition indicates a complex set of activities, in addition to the time spent at seminars or lectures, it also includes all other study-related activities. Our present study examines the concept of academic time in higher education. After introducing the theoretical foundations of the study, I briefly summarize the findings of the relevant empirical research. The empirical analysis is based on Tertiary Education and Regional Development Research'si 2010 representative database (N=602) that targeted higher educational institutions at the Partium region. In the analysis, we attempted to explain the time spent with academic activities by socio-cultural variables (sex, type of settlement) as well as by the faculties attended and by students' part-time employment. Moreover, we analyzed the sample with regards to the clusters of value and leisure. The length of academic time was also compared to students' academic achievements. The explanatory variables had considerable effects on lifestyle, but we did not find connection with the academic achievement and academic time of students.
\end{abstract}

Keywords: higher education, students, learning, time, academic achievement

\section{Academic time and the world of higher education}

The lifestyle of full-time students in higher education has undergone fundamental changes in the past two decades. Such change can be grasped by looking at the system of activities (e.g. the time spent in employment), at the changing patterns of time distribution such as the decline of reading (Bocsi, 2013), but without doubt, it can also be traced in the strategies to merge different forms of activities (e.g. simultaneous activities). The main segments of student lifestyle such as the system of study-related activities, leisure time and employment have restructured, the emphases have shifted. The reasons behind this process are extremely complicated and can both be interpreted at a systemic level and based on changes in student life worlds. The broader context for these changes is the emergence of mass higher education, the changing student intake and the changing teaching requirements, and beyond the campus borders, the increase of complementary schooling age (Jancsák et al., 2012) and the increasing influence of leisure activities on stratification (Andorka, Hradil \& Peschar, 1995). The changes took place in the individual life worlds and in the rearrangement of value structures; and they are also due to the fact 
that the prevalence of hedonistic, more individual values push students towards the direction of a different, less rigid lifestyle.

It should be noted that the features of the activities have also changed considerably in the past few decades. So-called 'screen time' activities have overshadowed other informal leisure activities, but the use of computers has also left its mark on learning methods. Social networking sites are increasingly used for education management, while on-line exam questions with answers have changed the sources of studying.

Student lifestyle can be interpreted as balancing between many different types of roles and requirements (Horstmanshof \& Zimitat, 2007). Taking the perspective of the sociology of time as a starting point, we argue that time ranges connected to studying neatly fit into future-oriented thinking patterns and their dominance in lifestyle presumes an inner-directed human type (Riesman, Glazer \& Dennel, 1950). The dominant experience and presence of leisure is connected to hedonistic life conduct and present-orientation, while the consumption of cultural contents within these time ranges can be associated to long-term objectives. Students' employment has played a dominant role in the past few decades and this can both signal longterm and present orientation. In the case of non-traditional student groups, new types of requirements and roles became dominant, namely family-related tasks. The campus, the organization which loosely determines the temporal frames of lifestyle imposes certain restrictions on students' everyday activity structures, but a significant part of these choices is still due to individual decisions. However, due to limited resources, students need to make decisions that are bound to be value-guided and determined by socio-cultural status and time perspectives. A more rigid, learning-oriented way of life is only possible if it is supported by values coming from socialization or predictable outcome of the individual career. Lifetime spent in higher education can be interpreted as a period of accumulating cultural and human capital, nevertheless certain possibilities reach beyond the frames of academic time. The concept of 'academic leisure activities' used by George and colleagues (2008) also covers this category: according to the authors, reading, writing poetry and novels, journalism and taking part in debates belong to this category among others. But if academic degrees fail to ensure mobility, this way of life will no longer be desirable since sacrifices in the present do not result in positive changes in the future. Németh (2010) approaches this issue from the aspect of the durability of knowledge: if the pace of obsolescence increases, it raises the question whether learning-oriented student lifestyle will be rewarded at all or not. Due to the existing limitations, individual choices will naturally reduce the range of other activities. According to Ackerman and Gross (2003), the increase of time spent in employment reeduces students' leisure time. Kalenkoski and Pabilonia (2011) surveyed students in employment who attended a US secondary school and found that the time 
dedicated to studying, sleep and 'screen time' reduced. It is important to underline that defining certain activities as productive or unproductive is not always an unequivocal task: depending on its content and method, the use of Internet, reading, etc. have the potential to increase cultural and human capital.

\section{More academic time - better results?}

An important segment of the literature on academic time focuses on students' academic achievement. Out of the explanatory factors of achievement, several have temporal aspects. One thread of the analyses examines achievement in relation to academic time, but the connection between the two is not evident. A group of surveys argues about a modest positive relation, while other surveys failed to find relation between student achievement and academic time (Zulauf \& Gortner, 1999).

It should be noted however, that grasping the time expenditure in minutes leads to a narrowed angle that lack a holistic perspective: the more time spent at lectures is not likely to increase achievement, yet it signifies something completely different. Apart from this, academic achievement can also be influenced by effective learning techniques which can also reduce time expenditure. Surveys following an input-output logic also miss out how time is experienced, namely the postmodern pressure of time and the sense of time deprivation (Bocsi, 2012) also have considerable time management aspects. Using an US sample, Ackerman and Gross (2003) described these phenomena pointing out that student groups who have less leisure time and less free time resulted in higher achievement and satisfaction (the indicators of the latter were for instance the positive evaluation of lectures or positive relation to lecturers). Several surveys examine the relation between achievement and time management skills, since planning, monitoring and prioritising can effectively contribute to success at exams (Macan et al. 1990). Cemaloglu and Filiz (2010) proved the positive relation of planning to achievement in a sample of Turkish university students. George and colleagues (2008), using a US sample, also found this relation significant and they defined time management skills as a type of external resources which also has the potential effect to reduce other time bands. With regards to the student population examined, we may state that the students compared to other social groups bear relatively good time management skills and planning skills in particular (Cemaloglu \& Filiz, 2010).

\section{Changes in student lifestyle}

The international literature underlines that the time consumption of students can be mapped. Although not abundant, but sufficient research data is available on the different segments of higher education. Concerning students' time budget, it should 
also be noted that certain time units (e.g. screen time, reading) may be associated with academic time (Jacobsen \& Forste 2011; Mokhtari, Reichard \& Gardner 2009), while others without doubt fall into the category of free or leisure time. Before turning to figures in details, two characteristic features of the population's lifestyle should be highlighted. The first can be linked to Zulauf and Gortner (1999) who argue that students' life conduct resembles to the average US time schedule in proportionality, but in the case of students, study time substitutes work. The second significant feature is the restructuring of student lifestyle: in general, academic time is becoming less and less dominant. According to Babcock and Marks (2011), in 1961, the academic time of full-time students in the US amounted to 40 hours per week, while in the 2003 national sample, it was only 27 hours. At the same time, the amount of employment and free time increased. More time was spent with academic activities in the subsample of father/daughter with higher qualification and paid jobs and in the case of the white population. Jacobsen and Forste (2011) estimated academic time expenditure to be 5.5 hours per day. The decrease of students' academic time is an extremely complicated process: the causes lie in the changes of student intake and the change of institutional standards to improving conditions of educational equipment. This latter point draws our attention to the fact that the decrease of academic time cannot be unanimously evaluated as a negative phenomenon. In their survey conducted in 1997 at the University of Ohio, Zulauf and Gortner (1999) measured 19.5 hours of free time, 12.3 hours in employment, 10.4 hours of public transportation and 10.1 hours of watching TV per week, and they also recorded activities which seem to be less relevant with regards to Hungarian conditions: students spent 4.2 hours per week in student organizations. In a national sample, Babcock and Marks (2011) calculated 1.6 hours of voluntary work per week which shows that student activity structures vary by countries as well. Mokhtari, Reichard and Gardner (2009) found that students spent less time on reading. Broken down by day, they found that students spent 1.14 hours with recreational reading, 2.17 hours with academic reading, 1.93 hours with watching TV and 2.47 hours with using Internet. With log type time budget examination, the authors also surveyed simultaneous activities, and it clearly showed that academic reading is for $63 \%$, an individual activity, while using the Internet is done individually only by $13 \%$. According to Jacobsen and Forste's study (2011), in 2008, university students spent an average 52 minutes on social networking sites, and in addition to this, 30 minutes on writing and receiving e-mails and 45 minutes on messaging services. These results refer to the fact that the academic use of the Internet is only one possibility, and generally students tend not to use IT resources for studying.

Longitudinal figures concerning Hungary and the Partium region are unfortunately not available, but the figures of some cross section studies are known 
by us. Based on the 2005 research of the Regional University Research group ${ }^{\mathrm{iii}}$, we can state that compared to the student group examined by the KSH (Hungarian Central Statistical Office), the proportion of the so-called academic time seem to be rather high (attending lectures: 203 minutes, studying outside lectures: 131 minutes, auto-education: 39 minutes). Moreover, if we sum up the results (373 minutes), we get significant time expenditure even compared to the work time of the adult population. And if we add students' work-like activities to it, the sum of the fixed durations exceeds 400 minutes per day on average (412 minutes). However, we must also note that other segments such as housework or employment are less dominant (Bocsi, 2013), thus beside the relatively extensive academic time band, other activities might also be dominant. Apart from this we must emphasize that the figures mentioned above are means, and certain groups of students deviate from these figures. We reckon that the trends highlighted by international examinations have also been present in the past two decades in Hungary.

\section{Methodological frames}

Our analysis is based on the data of the TERD (Tertiary Education and Regional Development) survey conducted in 2010 about MA and MSc students' academic time use. We were able to assess the estimated daily average of academic time ranges: the estimated time frames of studying and of reading teaching material was separated and we also used the cumulative index of the two. The detailed description of the category of studying was not prescribed in the query, so we can only presume that students meant both studying at the lectures and studying at home by it.

Explanatory variables included sex, type of permanent place of residence (village, smaller town, county town-capital city), type of temporary place of residence (sublet, dormitory, commuting, local, owning a flat), economic capital (poor, satisfactory and well-to-do groups based on durable consumer goods), ${ }^{\text {iv }}$ and regular student employment. We also assessed the relation between academic time and student achievement, the latter was examined by an index of taking part in the National Scientific Students' Associations Conference (OTDK), publications, presenting at conferences and successful scholarships. ${ }^{\mathrm{v}}$

The sample size of the database balanced towards faculties and institutions is 602. The database includes the institutions of Partium within the borders of Hungary (University of Debrecen, College of Nyíregyháza), and Hungarian higher educational institutions abroad (Partium Christian University (PKE), Ferenc Rákóczi II. Transcarpathian Hungarian Institute (II. RFKMF). The breakdown by faculties with adequate frequencies produced the following subsamples: Partium Christian University, Ferenc Rákóczi II. Transcarpathian Hungarian Institute, Faculty of Agricultural and Food Sciences (DE MÉK), Faculty of Applied Economics and 
Rural Development (DE GVK), Faculty of Arts (DE BTK), Faculty of Informatics (DE IK), Faculty of Economics and Business Administration (DE KTK), Faculty of Health (DE ÁOC NFK), Faculty of Medicine (DE ÁOK) and Faculty of Science and Technology (DE TTK).

In the analysis, the following hypotheses were constructed:

(1) There is significant relation between time use and university faculties. We expected outstanding values from the Faculty of Medicine.

(2) With regards to the type of permanent place of residence, we presumed that commuting would result the decrease of academic time.

(3) The index of student achievement does not show significant relation with the cumulative index of academic time. Academic time is a complex phenomenon and we presumed that not all segments were related to achievement (publishing activity for example).

In the course of the analysis, means and variance analysis were used.

\section{Characteristics of academic time in the Partium region}

First we examined students' time structures. In the case of MA and MSc students, estimations showed that the daily time band spent on studying were an average of 167 minutes. 120 minutes was spent with study-related reading, while the cumulative index of academic time amounted to 272 minutes in total in 2010. This means about four and a half hours of fixed time band per day, which is surprisingly little compared to the adult population's time use and points out the fact that students have considerable autonomy and margin concerning their way of life. In the first graph, we can see that the estimated duration of free or leisure time equals the hours spent on studying, and informal reading also forms a considerable block in students' way of life. These timeframes are greater than the ones found in the Regional University Research in 2005, the reason for that is that the latter research was carried out in the pre-Bologna period, while the 2010 sample included only MA and MSc students. It should be noted that nearly 100 minutes per day was spent in employment on average, and this is also due to the restructuring of student activities.

Figure 1. Major blocks of student time bands based on the 2010 database (in minutes, $\mathrm{N}=602$, graph by the author) 


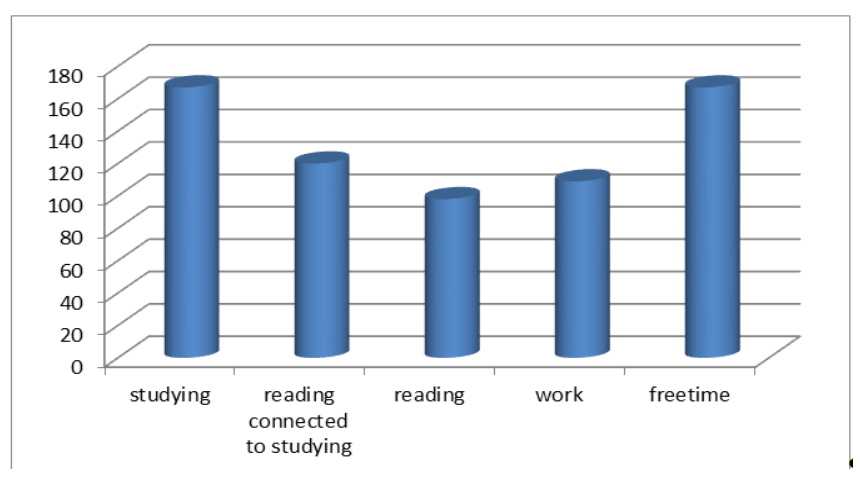

Next, the impact of major socio-cultural variables on academic time is explored. The variable of sex did not show significant relationship with the cumulative value of academic time, but if the data are further divided, we can see that the expenditure of study-related reading is higher in the case of females (ANOVA test, $p>0.05$, sig.: 0.027, 104 and 127 minutes). It is important to note that the Regional University Research that was based on a sample of undivided courses found bigger differences between the sexes. However, the differences in settlement type and study habits confirms our previous study, namely that students coming from county towns have the lowest expenditure. Of course, the type of university course also played a significant role because of the different lecture load and the possibility to 'minimize' lecture attendance (Graph 2). Study-related reading also displayed the lowest value in this subsample (101, 144 and 119 minutes).

Figure 2. Rate of academic time by settlement type (ANOVA test, p>0.05, sig.: 0.000, in minutes, $\mathrm{N}=602$, self-made graph).

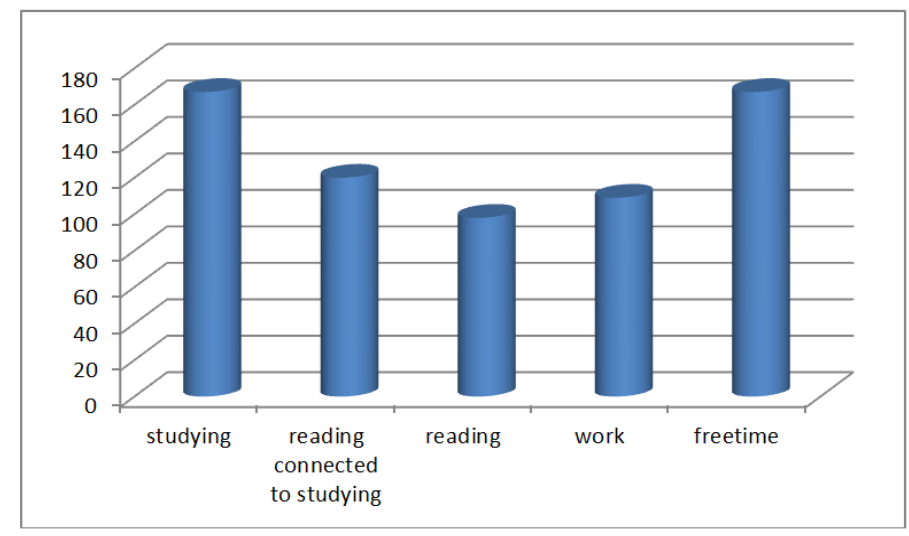

The groups formed based on the index of economic capital influenced the time of study-related reading (ANOVA-test, $\mathrm{p}>0.05$, sig.: 0.035). The higher the supply of durable consumer goods was, the lower was the estimated length of time spent on study-related reading (poorly supplied group: 135 minutes, satisfactorily supplied 
group: 113 minutes, well supplied group: 106 minutes). Our previous research evidenced that favourable financial situation has a negative effect on students' reading activity (Bocsi, 2013). Thus the student group that organically incorporates reading into their lifestyle seems to come from disadvantaged strata.

The variable of temporary place of residence (students living in a dormitory, commuting, living in sublets, local students, students owning a flat) influenced the length of time spent with studying as well as the cumulative figures. The ranges of time spent with studying were the highest in the case of students living in a dormitory (196 minutes), local students (160 minutes) and those living in sublets (150 minutes) represented intermediate values, while the timeframe of commuting students (142 minutes) and those owning a flat (120 minutes) was lower (ANOVAtest, $\mathrm{p}>0.05$, sig.: 0.06). The cumulative values are illustrated in Graph 3. Therefore it can be stated that commuting restricts time ranges spent with studying. But commuting students are forced to abandon other activities as well: their estimated daily free/leisure time is approximately 40 minutes less than the sample average.

Figure 3. The effect of temporary place of residence on the cumulative value of academic time (ANOVA-test, $\mathrm{p}>0.05$, sig.: 0.033, $\mathrm{N}=602$, self-made graph)

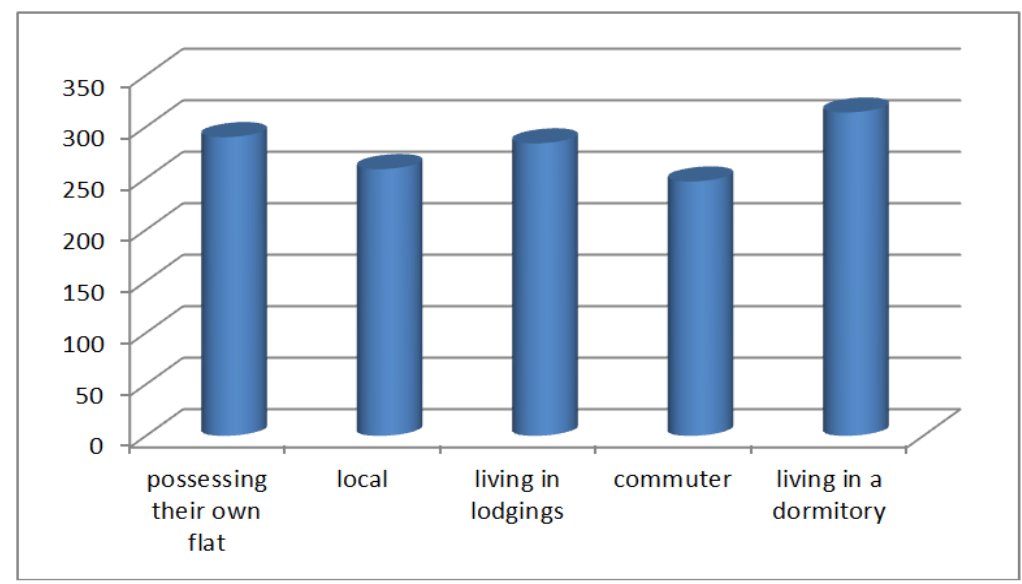

Breakdown by faculties could only be used where the number of items exceeded 25 participants per subsamples, hence ten faculty/institution variables could be included in our analysis (Graph 4). It should be noted that the institutions have peculiar learning habits and systems of requirements, which can considerably shape the use of academic time. We must also emphasize that certain characteristics of faculties/institutions (e.g. sex, distribution by settlement type) can influence the data obtained. Nevertheless, the unfolding picture shows the influence of organizational frames, there is a difference of about 200 minutes between the faculties representing the two opposite poles (University of Debrecen: Faculty of Economics and Business 
Administration and Faculty of Medicine), which generates fundamental differences in student lifestyle. The graph confirms the public image of the daily routine of medical students: their lifestyle is focused on studying. But it produces unexpected results as well, for example the approximately 3.5 hours long academic time band of economy students per day, or the relatively low time expenditure of the students in Beregszász as relatively low. However, it should be noted that the differences are not significant.

Figure 4. The connection between faculty/institution breakdown and academic time (ANOVA test, $\mathrm{p}>0.05$, sig.: 0.065, $\mathrm{N}=498$, self-made graph)

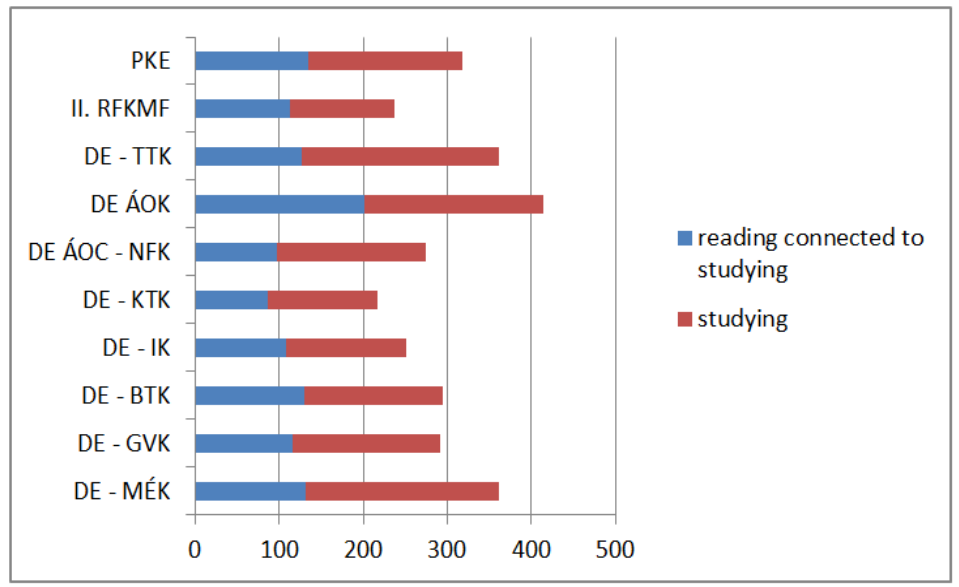

Nevertheless, if we analyze only studying and the time spent with studying by means of ANOVA test, significant relation can be found (Graph 5). There are rather serious differences: in the case of PKE students for instance, the range of time spent with study-related reading exceed the time spent with studying, while in the case of medical students (DE ÁOK), both studying and study-related reading are highly valued. In accordance with our previous surveys, it can be stated that in the case of DE KTK, students are not only doing less 'informal' reading, but also use less books related to their studies. It is worth highlighting that we found similar patterns in the case of DE BTK and DE TTK students as well.

Figure 5. The time spent with studying and study-related reading by faculty/institution (ANOVA-test, $\mathrm{p}>0.05$, sig.: 0.000 and $0.011, \mathrm{~N}=498$, graph by the author). 


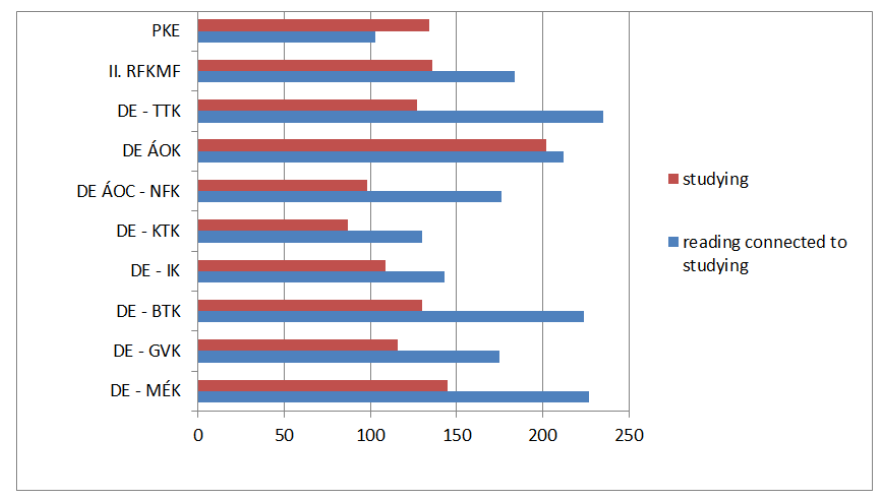

We presumed that student employment which has become an important element of student lifestyle in the past two decades would reduce the time spent on studying. Based on the TERD database, this relation seems to be significant also in the sample from Partium, thus it both reduces academic time as a whole and its elements too (Graph 6). The differences are approximately half an hour and an hour on average. However, it cannot be explained merely with quantitative methods whether this decrease signifies a more effective way to organize studies and rationalize them or that employment decreases study efficiency.

Figure 6. The connection between employment and academic time (ANOVA test, p>0.05, sig.: 0.032, 0.048 és $0.040, \mathrm{~N}=602$, self-made graph)

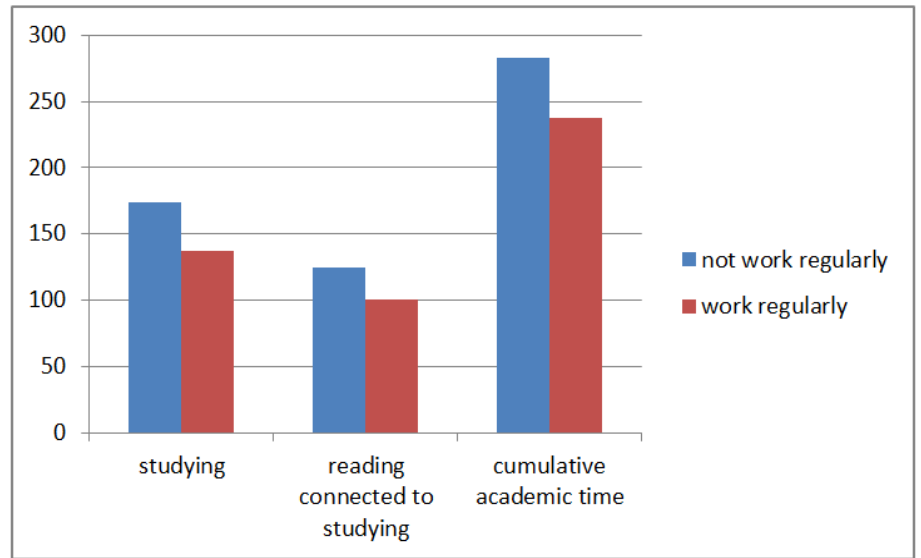

Finally, we set out to examine the connection between student achievement and academic time. We wanted to know whether high learning timeframes are necessary conditions of successful student achievement. First, we constructed an index from the items related to student achievement. Based on the index values, three subsamples of nearly the same size were created $(\mathrm{N}=105,159$ and 169), a group with low, medium and high achievement. When we took publications, conference presentations and registered memberships in a college for advanced studies as the 
basis of the result, we found that there isn't a connection between the two variables: it is not evidenced that in order to reach higher achievement, it is necessary to spend more time with studying. It should be noted that the evaluation of the decrease of time spent with studying is not unanimously negative in the international literature, as it may also denote more effective learning techniques and the acceleration of gaining information. So it seems that some part of the academic time can be interpreted as 'idle time' that is not used properly and rationally. The relevance of this concerning educational policy is that the mere expansion of academic time would not enhance study effectiveness.

\section{Summary}

After the review of results, we will examine the hypotheses. Our first hypothesis was that the variable of faculties/institutions will significantly change academic time as a whole and in particular elements too. This was only proved partially, as institutions and faculties influenced significantly only the different aspects of academic time, but not as a whole. The prognosis of high values for students attending the Faculty of Medicine (University of Debrecen) was proved. On the grounds of our earlier student time-budget surveys and based on the analysis of the adult population's lifestyle, we found that commuting has a peculiar effect on everyday routine activities and the amount of free time. We assumed that in the case of students crossing settlement borders the every day learning time would also reduce. Based on the results of the TERD database, it can be stated that this tendency is valid among students as well. Finally, we reckoned that academic time is not in direct connection with achievement: this statement was based on the fact that international examinations failed to discover a close and strong connection between the two and we also presumed that a considerable part of academic time is spent unproductively.

To summarize the major findings of the analysis, we could say that a significant part of students' time bands is covered by academic time, although 4.5 hours per day on average cannot be regarded as outstanding. The 'difficulty' of students' lifestyle - as it is confirmed by qualitative research (Bocsi 2013) - lies in the hectic nature of the days, in the frequency of idle periods and in its unpredictability and not in the degree of workload. Although longitudinal data are not available, we presume that a certain rearrangement have been taking place in students' everyday life, which is accompanied by the increasing importance of other spheres of activities (employment, free time). It is also important to note that the usage of academic time is embedded in socio-cultural and institutional factors, which was evidenced by its relation to settlement type or the faculty/institutional affiliation. Student lifestyle can be interpreted as balancing between different spheres and the decrease of academic time at the expense of work is an example for 
that.

At the same time we believe that the quantitative interpretation of academic time is only one dimension: the length of minutes and hours does not indicate the usefulness of the activity, the achievement of the learning process and its subjective interpretation. We are planning to explore these questions in the future by using qualitative research techniques.

\section{References}

Ackerman, S. D., \& Gross, L. B. (2003). Is time pressure all bad? Measuring the relationship between free time availability and student performance and perception. Marketing Educational Review, 13(2), 21-32.

Andorka R., Hradil, S., \& Peschar, J. L. (1995). Társadalmi rétegzödés [Social stratification]. Budapest: Aula Kiadó.

Babcock, B., \& Macks, M. (2011). The falling time cost of college: evidence from half a century of time use data. The Review of economic and statistics, 92(2), 468-478.

Bocsi V. (2013). Az idő a campusokon. [Time at campuses]. Szeged: Belvedere Meridionale.

Bocsi V. (2011). A posztmodern idő nyomában? A hallgatói életmód sajátosságai egy kvalitatív kutatás tükrében. [Following postmodern time? Peculiarities of student lifestyle reflected in a qualitative survey.] In E. Rákó (Ed.), Társadalomtudományi tanulmányok IV: Integráció - Inklúzió - Multikulturalitás (pp. 101-106). Debrecen: Debreceni Egyetemi Kiadó

Cemaloglu, N., \& Filiz, C. (2010). The relation between time management skills and academic achievement of potential teachers. Educational Research Quarterly, 33(4), 323.

Jancsák Cs., Ercsei K., Horkai A., Maticsák A., Szemerszki M., \& Tarnay I. (Eds.) (2012). Válogatott ifjúságszociológiai tanulmányok. [Selected youth sociological studies]. Szeged: Belvedere Meridionale.

George, D., Dicon, S., Stansal, E., Lund, Sh. G. \& Tabitha, Ph. (2008). Time diary and questionnaire assessment of factors associated with academic and personal success among university undergraduates. Journal of American College Health, 5(6), 706-715.

Horstmanhof, L., \& Zimitat, C. (2007). Future time orientation predicts academic engagement among first year university students. British Journal of Educational Psychology, 77(3), 703-718.

Jacobsen, C. W., \& Forste, R. (2011). The wired generation: academic and social outcomes of electronic media use among university student. Cyberpsychology, 14(5), 275-280.

Kalenkoski, M. CH., \& Pabilonia, S. (2011). Time to work or time to play: the effect of student employment on homework, sleep and screen time. U.S. Boureau of Labour Statistic, Working Paper 450. October. 
Macan, Th. H., Shahani, C., Dipboye, R. L., \& Phillips, A. P. (1990). College students' time management: correlations with academic performance and stress. Journal of Educational Psychology, 82(4), 760-768.

Mokhtari, K., Reichard, A. C., \& Gardner, A. (2009). The impact of internet and television use on the reading habits and practices of college students. Journal of Adolescence \& Adult Literacy, 52(7), 609-619.

Németh, A. (2010). Emberi idővilágok. Pedagógiai megközelítések [Human worlds of time. Pedagogical approaches.] Budapest: Gondolat Kiadó.

Riesman, D., Glazer D., \& Dennel, R. (1950). The lonely crowd: a study of the changing American character. New Haven: Yale University Press.

Zulauf, C. R., \& Gortner, A. K. (1999, August). Use of time and academic performance of college students - Does studying matter? Paper presented at the American Agricultural Economics Association, Annual Meeting, Ohio State University, Ohio, USA.

\footnotetext{
${ }^{i}$ The survey was conducted in the framework of the LEARN project (Learning Regions in Hungary: From Theories to Realities). Project head: Prof. Dr. Tamás Kozma.

ii OTKA-number: T-69 160. Research leader: Prof. Dr. Tamás Kozma.

iii NKFP-26-0060/2002. Research leader: Prof. Dr. Tamás Kozma.

iv The items examined were the following: owned flat, house, holiday home or plot, home computer, Internet subscription, hi-fi equipment, air conditioner, home theatre system, car, plasma TV.

${ }^{v}$ The items examined were the following: membership in a research group, participation in faculty/institutional research, TDK (Students' Scientific Association) paper, demonstrator position, publications, Hungarian résumé, foreign language résumé, scientific scholarship, membership in a college for advanced studies, university academic scholarship, other scholarship, participation in national conference, participation in international conference, participation in national research, class or group representative position, participation in international research, teaching private students, participation in talent support programmes, grant of the Republic of Hungary, independent work of art or other.
} 